\title{
ANALISIS PERLAKUAN AKUNTANSI PENDAPATAN DAN BEBAN JASA KONSTRUKSI DALAM RANGKA PERHITUNGAN LABA KOTOR PT. DJASA UBER SAKTI
}

\author{
Oleh : \\ Adolpino Nainggolan, SE.,M.Ak \\ Dan \\ Riza Satria Nugraha \\ Fakultas Ekonomi Akuntansi \\ Universitas Satya Negara Indonesia
}

\begin{abstract}
ABSTRAK
Tujuan penelitian ini adalah untuk mengetahui bagaimana metode pengakuan pendapatan dan beban jasa kontruksi yang diterapkan perusahaan dan metode pengakuan pendapatan dan beban jasa kontruksi tersebut dapat digunakan untuk menghitung laba kotor telah sesuai dengan Standar akuntansi Keuangan yang berlaku umum

Jenis data yang dipergunakan oleh penelitian ini adalah data primer dan data sekunder. Teknik analisis data yang digunakan dalam penelitian ini adalah deskriptif kualitatif, dengan membandingkan antara teori dan fakta yang terjadi secara deskriptif.

Hasil penelitian menunjukkan bahwa kebijakan pengakuan pendapatan dan beban belum sesuai dengan Standar Akuntansi Keuangan yang berlaku umum, sehingga pengakuan pendapatan tahun 2014 yang diakui perusahaan lebih besar Rp. 46.800.000,dibandingkan dengan Standar Akuntansi Keuangan, sebaliknya tahun 2015 pendapatan diakui yang perusahaan lebih kecil Rp. 46.800.000,- dibandingkan dengan Standar Akuntansi Keuangan. Sedangkan biaya yang dikeluarkan oleh perusahaan pada tahun 2014 lebih besar Rp. 139.000.000,- dibandingkan Standar Akuntansi Keuangan, sebaliknya tahun 2015 biaya yang dikeluarkan oleh perusahaan lebih kecil Rp. 139.000.000 dibandingkan Standar Akuntansi Keuangan. Laba yang diakui yang diakui perusahaan tahun 2014 lebih kecil Rp. 92.200.000,- dibandingkan dengan Pernyataan Akuntansi Keuangan dan sebaliknya pada tahun 2015 laba yang diakui oleh perusahaan lebih besar RP. 92.200.000,- dibandingkan dengan Standar Akuntansi Keuangan.
\end{abstract}

Kata Kunci : Perlakuan Akuntansi Pendapatan dan Beban Jasa Konstruksi 


\section{PENDAHULUAN}

\section{Latar Belakang Penelitian}

Salah satu bidang usaha yang sangat berperan dalam pembangunan terutama dalam memberikan jasa pelayanan untuk membangunan berbagai macam sarana dan prasarana yang dibutuhkan masyarakat adalah industri jasa konstruksi. Kemajuan disektor ekonomi yang didukung dengan berkembangnya teknologi akan menyadarkan masyarakat akan intesitas kebutuhan pembangunan fisik seperti pembangunan perumahaan, perkantoran, jalan, jembatan, plaza, pabrik dan lan sebagainya

Masyarakat pengguna jasa konstruksi sangat menyadari pentingnya jasa kontraktor yang dapat menunjang keberhasilan program-program pembangunan sarana dan prasarana tersebut sesuai dengan kebutuhan mereka. Perusahaan jasa konstraktor adalah pihak yang dapat mengerjakan program-program pembangunan tersebut yang dilakukan melalui salah satu proses pengerjaan mulai perencanaan oleh biro tehnik atau arsitektur, jasa perbaikan dan konstruksi bangunan serta kegiatan-kegiatan lain yang berhubungan dengan aktivitas jasa kontruksi.

Perusahaan jasa kontraktor biasanya mengerjakan pekerjaan konstruksi dilaksanakan dalam jangka waktu yang cukup lama, sehingga dapat melampaui jangka waktu periode akuntansi yang normal. Dalam hal ini menimbulkan masalah dalam penakuan pendapatan yang diterima dan biaya yang harus dikeluarkan oleh perusahaan tersebut, yang dapat mempengaruhi besarnya laba atau rugi perusahaan untuk suatu periode akuntansi. Pembiayaan pelaksanaan pekerjaan konstruksi tersebut sangat tergantung pada pendapatan yang diterima dari pemberi kerja dan merupakan kebiasaan dalam dunia usaha konstruksi bahwa setiap kontrak pekerjaan akan selalu ditentukan syarat pembayaran berdasarkan kontrak penjualan.

Metode umum yang digunakan pada perusahaan jasa kontraktor dalam mengakui pendapatan adalah metode persentase penyelesaian dan metode kontrak selesai. Pada metode persentase penyelesaian, pendapatan diakui tidak langsung pada saat proyek proyek diselesaikan melainkan pada saat proyek dalam proses penyelesaiaan. Pendapatan diakui sebesar persentase perbandingan biaya atau dengan menggunakan persentase penyelesaian fisik. Dalam hal ini akan ada laba yang dilaporkan dalam satu satu periode akantansi pada persentase yang ditetapkan, sehingga pada akhir periode konstruksi laba yang dilaporkan tidak terlalu besar.

Dalam metode kontrak selesai, pendapatan diakui pada saat proyek telah selesai seluruhnya. Secara praktek metode kontrak selesai masih diterapkan dengan alasan lebih praktis, karena laba untuk satu periode akuntansi dapat segera ditentukan dengan cara mengurangi seluruh pendapatan yang diterima dari kontrak proyek dengan biayabiaya yang dikeluarkan untuk menyelesaikan proyek tersebut. Dalam hal ini laba merupakan salah satu aspek penting bagi perusahaan dalam mengukur keberhasilannya. 
Bertitik tolak dari uraian di atas, penulis melihat bahwa pengakuan pendapatan dan biaya merupakan salah satu faktor yang penting dalam menunjang perolehan laba bagi perusahaan. Oleh karena itu peniliti tertarik untuk menulis skripsi ini dengan judul "ANALISIS PERLAKUAN AKUNTANSI PENDAPATAN DAN BEBAN JASA KONSTRUKSI DALAM RANGKA PERHITUNGAN LABA KOTOR PT. DJASA UBER SAKTI"

\section{LANDASAN TEORI}

\section{Pengertian Pendapatan.}

Pendapatan merupakan unsur penting bagi kesinambungan perusahaan yang bermotif untuk mendapatkan laba dalam operasi kegiatannya, karena besar kecilnya laba yang diperoleh suatu perusahaan ditentukan oleh besar kecilnya pendapatan dan beban yang terjadi dalam suatu perusahan tersebut.

Pengertian pendapatan menurut Eldon S Hendrikson (2007:173) menyatakan: Pendapatan adalah arus masuk aktiva sebagai hasil kegiatan operasi perusahaan dan yang lainnya berfokus pada penciptaan barang dan jasa oleh perusahaan serta penyalurannya kepada konsumen atau produsen lainnya.

Sedangkan menurut pendapat Donal E Kieso (2005:59) mendefinisikan pendapatan sebagai:

Arus masuk aktiva atau penyelesaian kewajiban dan penyerahan produk barang, pemberian jasa dan aktivitas pencarian laba yang merupakan operasi utama yang berkesinambungan selama satu periode

Dari definisi-definisi di atas penulis dapat menarik kesimpulan bahwa pendapatan adalah merupakan peningkatan aktiva dalam bentuk arus kas masuk dan penurunan kewajiban yang timbul dari kegiatan operasi perusahaan dan dilaporkan dalam laporan laba rugi dalam suatu periode.

Selanjutnya definisi di atas juga menyatakan bahwa pendapatan pada umumnya timbul dari kegiatan utama perusahaan yang terjadi berulang-ulang dalam suatu periode akuntansi. Misalkan pada prusahaan dagang, dimana kegiatan kegiatan utamanya adalah menjual barang dagangan, dimana penjualan tersebut tidak terjadi hanya satu kali, tetapi berulang kali. Kemungkinan lain adalah pendapatan akan timbul dari hak yang diberikan oleh perusahaan kepada pihak ketiga untuk menggunakan harta perusahaan. Misalnya, dalam hal perusahaan menyewakan gedung dan mesin, maka balas jasa yang diperoleh adalah berupa uang sewa, dimana akan diperoleh bunga atau deviden atas investasinya, selain itu ada juga pendapatan yang diperoleh dari kegiatan diluar kegiatan normal perusahaan, akan tetapi pendapatan tersebut hanya terjadi sekali-sekali saja. 
Dari uraian-uraian di atas, dapat disimpulkan bahwa sumber-sumber pendapatan suatu perusahaan dapat berasal dari:

1. Pendapatan Operational (Operating Revenue) yaitu pendapatan yang berasal dari kegiatan normal atau kegiatan utama perusahaan.

2. Pendapatan Dari Luar Perusahaan (Non Operating Revenue) yaitu pendapatan yang berasal dari transaksi diluar kegiatan utama perusahaan.

3. Pendapatan Luar Biasa (Extraordinary Revenue) yaitu pendapatan yang memenuhi kedua kriteria yang bersifat tidak normal dan jarang terjadi. Misalnya, keuntungan dari penjualan aktiva tetap perusahaan.

Secara garis besar Ikatan Akuntan Indonesia mengelompokkan pendapatan operasional ke dalam pendapatan utama dan pendapatan non operasional dikelompokkan kedalam pos luar biasa yang bersifat tidak normal dan tidak sering terjadi.

\section{Pengukuran dan Pengakuan Pendapatan. Pengukuran Pendapatan.}

Pendapatan sering dikaitkan dengan prosedur pengukuran dan penentuan waktu pengakuan pendapatan. Masalah pengakuan pendapatan tidak dapat dilepaskan dari masalah pengukuran dan penentuan waktu pengakuan pendapatan dimaksud. Bagaimanapun pendapatan didefinisikan, namun cara yang terbaik untuk mengukur pendapatan menurut Ikatan Akuntan Indonesia dalam bukunya Standar Akuntansi Keuangan menyatakan bahwa "Pendapatan harus diukur dengan nilai wajar imbalan yang diterima atau yang dapat diterima".

Pada umumnya nilai wajar imbalan yang diterima atau yang dapat diterima dalam suatu perusahaan menurut definisi di atas adalah nilai tukar produk atau jasa yang dapat diukur atau di ekuivalen kedalam kas atau nilai sekarang dari pendiskontoan tagihan uang yang akhirnya akan diterima dari transaksi pendapatan.

Oleh karena itu perlu diperhitungkan pengurangan-pengurangan terhadap pendapatan, misalnya retur penjualan dan potongan-potongan lainnya sebagai pengurangan dari pendapatan.

\section{Pengakuan Pendapatan.}

Ikatan Akuntan Indonesia menyatakan bahwa "Pengakuan pendapatan dengan acuan pada tingkat penyelesaian suatu transaksi sering disebut sebagai suatu persentase penyelesaian".Menurut metode ini, pendapatan diakui dalam periode akuntansi pada saat jasa diberikan. Pengakuan pendapatan atas dasar jasa ini memberikan informasi yang berguna mengenai tingkat kegiatan jasa dan kinerja suatu perusahaan dalam suatu periode.

Dari definisi tersebut dapat disimpulkan bahwa pengakuan pendapatan diakui pada saat realisasinya yaitu pada saat jasa diberikan. Istilah realisasi digunakan para akuntan untuk menunjukkan kapan saat pencatatan pendapatan dilakukan . 
Selanjutnya penjabaran tenggang waktu pengakuan pendapatan ( 2002: PSAK No.23.14-23.26) sebagai berikut:

a. Penjualan Barang Dagangan

Pendapatan dari penjualan barang dagangan harus diakui bila seluruh kondisi berikut dipenuhi :

1) perusahaan telah memindahkan resiko secara signifikan dan telah memindahkan manfaat kepemilikan barang kepada pembeli

2) perusahaan tidak lagi mengelola atau melakukan pengendalian efektif atas barang yang dijual

3) jumlah pendapatan tersebut dapat diukur dengan handal

4) besar kemungkinan manfaat ekonomi yang dihubungkan dengan transaksi akan mengalir kepada perusahaan tersebut; dan

5) biaya yang terjadi atau yang akan terjadi sehubungan dengan transaksi penjualan dapat diukur dengan handal

b. Penjualan Jasa

Bila hasil suatu transaksi yang meliputi penjualan barang dan jasa dapat di estimasi dengan handal, sehubungan dengan transaksi tersebut harus diakui dengan acuan pada tingkat penyelesaian dari transaksi pada tanggal neraca. Hasil suatu transaksi dapat di estimasi dengan handal bila seluruh kondisi berikut ini dipenuhi :

1) jumlah pendapatan pendapatan dapat diukur

2) besar kemungkinan manfaat ekonomi sehubungan dengan transaksi tersebut akan diperoleh perusahaan

3) tingkat penyelesaian dari suatu transaksi pada tanggal neraca dapat diukur dengan handal

4) biaya yang terjadi untuk transaksi tersebut dan biaya untuk menyelesaikan transaksi tersebut dapat diukur dengan handal

Bila hasil transaksi yang meliputi penjualan jasa tidak dapat diestimasi dengan handal, pendapatan yang diakui hanya yang berkaitan dengan beban yang telah diakui yang dapat diperoleh kembali

c. Pendapatan yang timbul dari penggunaan aktiva perusahaan oleh pihak-pihak lain yang menghasilkan bunga, royalty dan deviden harus diakui atas dasar :

1) besar kemungkinan manfaat ekonomi sehubungan dengan transksi tersebut akan diperoleh perusahaan ; dan

2) jumlah pendapatan dapat diukur dengan

handal Pendapatan harus diakui dengan dasar sebagai

berikut :

1) bunga harus diakui atas dasar proporsi waktu yang memperhitungkan hasil efektif aktiva tersebut

2) royalty harus diakui atas dasar akrual sesuai dengan substansi perjanjian yang relevan; dan

3) dalam metode biaya (cost method), deviden tunai harus diakui bila hak pemegang saham untuk menerima pembayaran ditetapkan

\section{Metode Pengakuan Pendapatan Pada Perusahaan Kontraktor.}

Proyek-proyek konstruksi yang dikerjakan oleh perusahaan kontraktor mempunyai jangka wkatu yang bervariasi, ada yang berjangka panjang (lebih dari satu tahun) dan berjangka pendek (kurang dari satu tahun). Sebagian proyek dapat dikerjakan dalam jangka waktu kurang dari periode akuntansi, sedangkan sebagian 
lainnya mencapai beberapa periode akuntansi. Karena hal tersebut maka terdapat 2 metode pengakuan pendapatan pada perusahaan kontraktor yaitu Metode Persentase Penyelesaian (Percentage of Completion Method) dan Metode Kontrak Selesai (Completed Contract Method)

\section{Metode Persentase Penyelesaian (Percentage of Completion Method)}

Menurut metode persentase penyelesaian, perusahaan mengakui pendapatan dan biaya sesuai dengan kemajuan perusahaan menyelesaikan kontrak dan tidak menangguhkan pengakuan unsusr-unsur tersebut sampai kontrak telah diselesaikan.

Jumlah pendapatan yang diakui didasarkan pada ukuran tertentu dari kemajuan penyelesaian dan pengukuran ini memerlukan taksiran mengenai biaya-biaya yang masih akan dikeluarkan. Timbulanya perubahaan taksiran dikemudian hari merupakan hal yang biasa dan akan diadakan penyesuaian pada periode akuntansi dimana taksiran itu direvisi.

Hal tersebut sesuai dengan pernyataan Ikatan Akuntan Indonesia dalam bukunya Standar Akuntansi Indonesia (2002 :PSAK No. 34) yang menyatakan bahwa "pendapatan kontrak diukur pada nilai wajar dari imbalan yang diterima atau yang akan diterima".

Pengukuran pendapatan kontrak dipengaruhi oleh bermacam-macam ketidakpastian yang tergantung pada hasil peristiwa dimasa yang akan datang. Estimasinya seringkali harus direvisi sesuai dengan realisasi dan hilangnya ketidakpastian.

Dengan demikian pendapatan dan biaya yang akan diakui dalam suatu tahun tertentu dipengaruhi oleh pendapatan pendapatan dan biaya yang diakui. Biaya yang sebenarnya dikeluarkan dan laba yang diakui selama periode pembangunan dibebankan pada persediaan. Jika perusahaan memproyeksikan adanya kerugian atas kontrak sebelum penyelesaian jumlahnya harus segera diakui.

\section{a. Ukuran Masukan (Input Measures)}

Ukuran masukan dibuat sehubungan dengan upaya atas biaya yang dicurahkan untuk suatu kontrak, meliputi metode biaya-ke-biaya (cost-to-cost method) dan variasi dari metode usaha yang dicurahkan (efforts-expended method)

1). Metode Biaya-ke-Biaya (Cost-to-Cost Method)

Metode ini yang sering digunakan dalam praktek. Dalam metode ini, tingkat persentase penyelesaian ditentukan dengan membandingkan biaya-biaya yang sudah dikeluarkan dengan taksiran terbaru mengenai jumlah seluruh biaya yang diharapkan untuk menyelesaikan suatau proyek. Beberapa dari biaya yang dikeluarkan terutama pada tahap-tahap awal kontrak, harus dilupakan karena biayabiaya ini tidak secara langsung berhubungan dengan usaha yang dicurahkan untuk kontrak tersebut. Biaya-biaya ini meliputi seperti biaya sub kontraktor untuk pekerjaan yang masih harus dilaksanakan dan standar pemakaian bahan yang belum dibuat. Yang menjadi masalah dalam menggunakan metode ini adalah sulitnya 
mengestimasi biaya yang akan dikeluarkan, namun taksiran ini diperlukan dalam melaporkan laba tanpa memperhatikan bagaimana persentase penyelesaian itu dihitung.

Rumus yang digunakan menurut dalam metode ini adalah sebagai berikut :

\section{Persentase $=$ Biava-biava vang dikeluarkann sampai akhir peride berjalan}

Selesai Taksiran jumlah seluruh biaya yang terbaru

Untuk mendapatkan jumlah pendapatan atau laba kotor tahun berjalan, persentase penyelesaian proyek dikalikan dengan total pendapatan dikurangi pendapatan kotor yang diakui pada periode sebelumnya yang diharapkan dari proyek tersebut.

Rumus yang digunakan menurut dalam metode ini adalah sebagai berikut:

$\begin{array}{lll}\text { Biaya-biaya yang } & \text { Jumlah taksiran } & \begin{array}{l}\text { Jumlah } \\ \text { pendapatan } \\ \text { yang diakui pada } \\ \text { periode } \\ \text { Dikeluarkan sampai saat sekarang x }\end{array} \\ \text { Taksiran seluruh biaya } & \text { seluruh pendapatan } & \text { sebelumnya }\end{array}$

\section{2). Metode Usaha Yang Dicurahkan (Efforts-Expended Method)}

Dalam metode ini, tingkat persentase penyelesaian didasarkan pada ukuran tertentu dari pekerjaan yang dilaksanakan. Ukuran ini meliputi jam kerja, upah buruh, jam mesin, atau kuantitas bahan. Tingkat penyelesaian diukur dengan cara yang sama dengan pendekatan biaya-ke-biaya.

\section{b. Ukuran Keluaran (Output Measures)}

Ukuran ini dibuat dengan hasil yang dicapai, termasuk dalam kategori ini adalah metode-metode yang didasarkan pada unit yang dihasilkan dan pertambahan nilai (value added). Contoh, jika kontrak menghendaki unit keluaran seperti panjang jalan raya dalam kilometer, maka ukuran penyelesaian adalah rasio dari panjang jalan yang sudah diselesaikan terhadap panjang jalan menurut kontrak. Para arsitek sering diminta untuk mengevaluasi berbagai pekerjaan kemudian menaksir berapa persentase pekerjaan selesai. Taksiran ini merupakan ukuran keluaran dan biasanya didasarkan pada kemajuan fisik yang sudah tercapai atas suatu kontrak.

Keuntungan dari penggunaan metode persentase penyelesaian sebagai berikut:

1) Pendapatan diakui secara periodik sesuai dengan pekerjaan yang telah diselesaikan, sehingga dapat dilakukannya konsep matching cost terhadap revenue secara periodik

2) Laba dari kontrak yang belum selesai dapat ditentukan secara jelas, dengan melihat estimasi-estimasi yang harus dilakukan terhadap biaya-biaya penyelesaian

Kelemahan dari penggunaan metode persentase penyelesaian sebagai berikut: 
a) Metode ini menganggap profit timbul karena biaya telah dikeluarkan, sedangkan kegiatan yang penting mungkin terjadi pada tingkat perencanaan yaitu sebelum biaya yang besar dikeluarkan

b) Persentase penyelesaian dihitung dengan menggunakan biaya total proyek sebagai penyebut, padahal biaya total inipun termasuk sesuatu yang tidak diketahui dengan pasti. Biaya total proyek kebanyakan baru diketahui setelah proyek selesai

\section{Metode Kontrak Selesai (Completed Contract Method)}

Menurut metode ini pendapatan diakui hanya pada saat kontrak diselesaikan dan diserahkan kepada pembeli. Metode ini sesuai dengan konsep relisasi yaitu pendapatan dikaui apabila terjadi penjualan, sehingga keuntungan berasal dari penjualan dan bukan berasal dari produksi. Disini semua biaya dapat dibebankan sebagai defferd cost atau biaya yang ditangguhkan menunggu sampai kontrak selesai. Metode kontrak selesai digunakan untuk kontrak jangka pendek dan apabila metode persentase penyelesaian tidak dapat diterapkan.

Kelebihan metode kontrak selesai adalah pelaporan pendapatan didasarkan pada hasil akhir dan bukan pada taksiran pekerjaan yang belum dilakukan. Kekurangannya adalah tidak mencerminkan prestasi kerja masa berjalan bila periode kontrak tersebut diperpanjang menjadi lebih dari satu periode akuntansi. Meskipun pelaksanaannya cukup seragam namun pendapatan yang tidak dilaporkan sampai tahun penyelesaiannya menimbulkan penyimpangan dalam laba. Dengan demikian metode ini mengakibatkan kegagalan dalam matching cost dengan revenue secara periodik.

\section{Akuntansi Untuk Perusahaan Kontraktor}

Untuk memberikan gambaran yang lebih jelas pencatatan pengakuan pendapatan pada perusahaan kontraktor, berikut ini akan diberikan sebuah contoh. Diasumsikan suatu perusahaan kontraktor menerima kontrak pembangunan pada awal tahun 20X8 dan kontrak tersebut diselesaikan pada akhir tahun 20X9. Jurnal transaksi yang lazim untuk mencatat pembangunan tersebut adalah:

Perbedaan antara metode persentase penyelesaian dengan kontrak selesai ada pada metode pengakuan pendapatan pada akhir tahun. Pendapatan atas proyek pada metode perentase penyelesaian diakui pada setiap peiode atas dasar persentase kemajuan penyelesaian proyek, sedangkan metode kontrak selesai pendapatan dikakui pada saat penyerahan proyek 


\section{METODOLOGI PENELITIAN}

\section{Waktu dan Tempat Penelitian}

\section{a) Waktu Penelitian}

Penelitian ini akan dilakukan mulai bulan Oktober 2015 sampai Januari 2016.

\section{b) Tempat Penelitian}

Penelitian dilaksanakan pada perusahaan "PT. Djasa Uber Sakti" yang berlokasi di Jalan Karang Tengah Bona Indah Plaza Blok A2/B8, Lebak Bulus

\section{Desain Penelitian}

Desain penelitian yang digunakan adalah penelitian deskriptif, merupakan penelitian yang bertujuan untuk membuat deskripsi secara sistematis, faktual dan akurat mengenai fakta-fakta dan sifat-sifat dari populasi (objek) penelitian. Permasalahan dalam penelitian ini adalah studi kasus. Studi kasus dengan metode deskriptif ini digunakan untuk menjelaskan pemecahan masalah berdasarkan data sesuai dengan masalah yang diteliti.

\section{Metode Pengumpulan Data}

a) Ada dua cara pengumpulan data penelitian yaitu :

1) Metode Penelitian Lapangan (Field Research) adalah metode dengan mengunjungi objek penelitian guna memperoleh data-data dan informasi yang diperlukan untuk penyusunan penelitian tersebut.

2) Metode Penelitian Kepustakaan (library research) adalah metode pengumpulan data dengan cara membaca dan mempelajari buku-buku yang ada dan sumber data yang lainnya berkaitan dengan pembahasan masalah yang dibutuhkan.

b) Teknik pengumpulan data pada penelitian ini adalah dengan melakukan wawancara, observasi dan survei dokumen secara langsung kegiatan yang berhubungan permasalahan penelitian.

1) Teknik wawancara yaitu memperoleh data dengan cara melakukan tanya jawab secara langsung kepada pihak yang berwenang seperti bagian proyek dan bagian akuntansi.

2) Teknik observasi yaitu mengumpulkan data secara detail. dengan cara mengumpulkan dokumen-dokumen yang berkaitan dengan permasalahan penelitian seperti berita acara proyek, laporan biaya proyek, laporan persentease penyelesaian proyek dan laporan keuangan.

\section{Jenis Data}

Dalam penelitian ini jenis data yang dipergunakan oleh peneliti adalah data primer dan data sekunder. Data primer adalah data yang diperoleh langsung dari objek yang diteliti atau dari sumber aslinya, seperti hasil wawancara dan observasi secara langsung. Sedangkan data sekunder adalah data primer yang telah diolah lebih lanjut dan telah disajikan oleh pihak lain. 
Sumber data sekunder yang dipakai dalam penelitian ini yaitu sumber data internal, sumber data intenal yaitu data yang bersifat intern atau dari dalam suatu perusahaan yang bersangkutan.

\section{Metode Analisis Data}

Teknik analisis data yang digunakan dalam penelitian ini adalah deskriptif kualitatif. Teknik analisis data yang dipakai pada penelitian ini yaitu dengan membandingkan antara teori dan fakta yang terjadi secara deskriptif.

Adapun pengertian tentang penelitian deskriptif menurut Suharsimin Arikunto, (1998:245) analisis deskriptif merupakan kajian non hipotesis sehingga dalam langkah penelitiannya tidak perlu merumuskan hipotesis.

\section{HASIL DAN ANALISA PEMBAHASAN}

\section{Metode Pengakuan Pendapatan dan Beban Pada PT Djasa Uber Sakti}

PT. Djasa Uber Sakti menggunakan metode persentase penyelesaian sesuai dengan kontrak untuk mengakui pendapatan atas kontrak pekerjaan yang dilakukan. Dalam metode tersebut, pendapatan atas kontrak diakui pada akhir periode akuntansi walaupun kontrak belum seluruhnya selesai dikerjakan. Alasan perusahaan menggunakan metode persentase penyelesaian adalah:

a. Metode ini dianggap lebih hemat karena tidak perlu mengeluarkan modal yang lebih banyak dan berisko lebih rendah, sebab bila terjadi sesuatu hal yang tidak diinginkan, misalnya ketidak mampuan pemberi kerja melakukan pembayaran pada saat yang telah ditentukan atau pemberi kerja pailit, maka pihak perusahan dapat menghentikan pekerjaaannya. Dibandingkan dengan metode kontrak selesai yang berisiko lebih besar dan memerlukan modal yang lebih besar, karena pembayaran akan diterima jika pekerjaan telah selesai dikerjakan seluruhnya.

b. Dengan menggunakan metode ini, dapat diketahui laba rugi periodik untuk tiap-tiap kontrak

c. Dengan menggunakan metode persentase penyelesaian sesuai dengan kontrak, maka besarnya pendapatan yang diakui pada setiap akhir periode akuntansi adalah sebesar jumlah termin-termin kontrak yang ditagih pada periode yang bersangkutan. Jumlah termin kontrak yang dapat ditagih oleh perusahaan sudah diatur dalam kontrak, yang mana termin dapat ditagih jika fisik pekerjaan telah mencapai persentase tertentu. Persentase penyelesaian fisik pekerjaan ini selanjutnya akan dikalikan dengan nilai kontrak untuk mendapatkan jumlah termin yang akan ditagih.

Untuk peroide akuntansi berikutnya, pengukuran pendapatan dilakukan dengan cara menghitung kembali penyelesaian fisik pekerjaan seluruhnya dari awal pelaksanaan. Besarnya perentase fisik yang dihasilkan kemudian dikurangi dengan persentase fisik pekerjaan yang telah ditagih pada terminnya pada periode-periode sebelumnya. Sisanya merupakan persentase fisik pekerjaan yang digunakan untuk 
menagih termin pada periode tersebut yang kemudian akan digunakan untuk mengakui pendapatan kontrak.

\section{Perbandingan Pengakuan Pendapatan PT Djasa Uber Sakti dan PSAK No 23}

Dengan perhitungan dan jurnal yang telah diuraikan di atas, maka pengakuan pendapatan yang telah dilakukan oleh perusahaan tidak sesuai PSAK No. 23, tetapi dilakukan sesuai dengan persentase penyelesaian kontrak, sehingga terdapat perbedaan pengakuan pendapatan dan biaya proyek antara perhitungan berdasarkan kontrak dengan perhitungan berdasarkan PSAK yaitu sebagai berikut:

Tabel

Pendapatan dan Biaya

Proyek

Untuk Tahun 2014

\begin{tabular}{|l|l|l|l|}
\hline Keterangan & Perusahaan & PSAK & Selisih \\
\hline Pendapatan & Rp. 1.440 .000 .000 & Rp. 1.393.200.000 & Rp. 46.800.000 \\
Biaya Proyek & Rp. 1.300.000.000 & Rp. 1.161.000.000 & Rp. 139.000.000 \\
\hline Laba Kotor & Rp. 140.000 .000 & Rp. 232.200.000 & (Rp. 92.000.000) \\
\hline
\end{tabular}

Sumber: Data yang diolah

Tabel

Pendapatan dan Biaya

Proyek

Untuk Tahun 2015

\begin{tabular}{|l|l|l|l|}
\hline Keterangan & Perusahaan & PSAK & Selisih \\
\hline Pendapatan & Rp. 360.000.000 & Rp. 406.800.000 & (Rp. 46.800.000) \\
Biaya Proyek & Rp. 200.000.000 & Rp. 339.000.000 & (Rp. 139.000.000) \\
\hline Laba Kotor & Rp. 160.000.000 & Rp. 67.800.000 & Rp. 92.200.000 \\
\hline
\end{tabular}

Sumber: Data yang diolah

\section{Hasil Penelitian}

Dari tabel di atas dapat diketahui bahwa pendapatan tahun 2014 yang diakui oleh perusahaan lebih besar Rp. 46.800 .000 dibandingkan dengan PSAK dan sebaliknya untuk pengakuan pendapatan yang diakui oleh perusahaan lebih kecil Rp. 46.800.000 dibandingkan dengan PSAK

Sedangkan biaya yang dikeluarkan perusahaan untuk proyek dalam tahun 2015 lebih besar Rp. 139.000.000 dibandingkan dengan PSAK dan sebaliknya biaya yang dikeluarkan oleh perusahaan untuk proyek oleh perusahaan lebih kecil Rp. 139.000.000 dibandingkan dengan PSAK

Dari tabel 4.14 dan 4.15 di atas dapat diketahui laba kotor yang diakui oleh perusahaan pada tahun 2014 lebih kecil dibandingkan dengan laba kotor yang seharusnya diakui berdasarkan PSAK yaitu Rp. 97.200.000 atau sebesar 39.7\% dari laba kotor yang sesuai dengan PSAK NO. 23. 
Sebaliknya dalam tahun 2015 laba kotor yang diakui oleh perusahaan lebih besar dibandingkan dengan laba kotor berdasarkan PSAK No. 23yaitu Rp. 92.200.000 atau sebesar $57.6 \%$ dari laba kotor kotor yang sesuai dengan PSAK No. 23.

Dengan adanya penyimpangan yang dilakukan oleh perusahaan dalam mengakui pendapatan sesuai dengan persentase penyelesaian yang tertera dalam kontrak, bukan berdasarkan persentase penyeleasaian, maka akan menimbulkan kesalahan dalam pengambilan keputusan dalam tahun tersebut, misalnya dalam pengambilan keputusan untuk perhitungan hutang pajak penghasilan badan, pembagian komisi dan lain. Sebagai contoh dalam tahun 2014 perusahaan mengakui laba sebesar Rp. 140.000.000 yang seharusnya menurut PSAK No. 23 adalah sebesar Rp. 232.200.000, kondisi demikian dapat mengakibatkan perhitungan hutang pajak penghasilan badan akan menjadi kecil dari yang seharusnya, sehingga pada saat perhitungan pajak penghasilan final, PT. Djasa Uber Sakti perlu melakukan koreksi fiskal atas laba perusahaan untuk menyesuaikan kekurangan perhitungan pajak penghasilan tersebut yang implikasinya hutang pajak akan bertambah dan pembayaran pajak akan lebih besar, hal ini dapat mengakibatkan terganggunya Cah Flow perusahaan.

\section{KESIMPULAN}

Dari hasil analisa dan pembahasan yang dilakukan, maka peneliti dapat menarik kesimpulan sebagai berikut :

a. Kebijakan pengakuan pendapatan yang dialkukan PT. Djasa Uber Sakti adalah berdasarkan pada besarnya persentase yang dilakukan dengan nilai kontrak sebagai dasar pengakuan pendapatan. Kebijakan ini bertentangan dengan Pernyataan Standar Akuntansi Keuangan (PSAK), dimana besar persentase untuk mengakui pendapatan adalah berdasarkan persentase penyelesaian fisik dari proyek tersebut

b. Pengakuan pendapatan pada tahun 2014 yang diakui perusahaan lebih besar Rp. 46.800.000,- dibandingkan dengan Pernyataan Standar Akuntansi Keuangan (PSAK) dan sebaliknya pada tahun 2015 pendapatan diakui oleh perusahaan lebih kecil Rp. 46.800.000,- dibandingkan dengan Pernyataan Standar Akuntansi Keuangan (PSAK). Sedangkan biaya yang dikeluarkan oleh perusahaan pada tahun 2014 lebih besar Rp. 139.000.000,- dibandingkan Pernyataan Standar Akuntansi Keuangan (PSAK) dan sebaliknya pada tahun 2015 biaya yang dikeluarkan oleh perusahaan lebih kecil Rp. 139.000.000 dibandingkan Pernyataan Standar Akuntansi Keuangan (PSAK)

c. Laba yang diakui yang diakui perusahaan tahun 2014 lebih kecil Rp. 92.200.000,dibandingkan dengan Pernyataan Standar Akuntansi Keuangan (PSAK) dan sebaliknya pada tahun 2015 laba yang diakui oleh perusahaan lebih besar RP. 92.200.000,- dibandingkan dengan Pernyataan Standar Akuntansi Keuangan (PSAK). 


\section{DAFTAR PUSTAKA}

Baridwan, Zaki, Intermediate Accounting, Edisi 7, Penerbit BPFE, Yogyakarta, 2005 Harison and Horngren, Akuntansi, Jilid I, Penerbit Salemba Empat, 1995

Hendriksen, Eldon S, Teori Akuntansi, Edisi 4, Jilid 1, Penerbit Erlangga, 2007

Ikatan Akuntan Indonesia, Standar Akuntansi Keuangan, Penerbit Salemba Empat, 2011

Robbins, Sthepen P, Perilaku Organisasi, Edisi 1, Jilid 2, Penerbit PT. Buana Ilmu Popular, 2006

Smith, Jay M and K. Fred Skousen, Intermediate Accounting, Edisi 9, Jilid 1 dan 2 Penerbit Salemba Empat, 2005

Supriyono, Akuntansi Biaya, Edisi 3, Jilid 1, Penerbit Erlangga, 2005

S.R. Soemarso, Akuntansi Suatu Pengantar, Jilid 1, Penerbit Rineka Cipta, 2005

Weygandh, Kieso and Kell, Accountung Principles, $4^{\text {th }}$ Edition, Jhon Willey and Sons, Inc, 2006 